\title{
IMPROVEMENT OF SUPPLY CHAIN MANAGEMENT IN THE FASHION INDUSTRY
}

\author{
Stanley CHIDIEBERE OGBURIE \\ Vytautus Magnus University \\ E-mail stanley.ogburie@stud.vdu.lt \\ ORCID ID: 0000-0002-3556-9235 \\ Jan ŽUKOVSKIS \\ Vytautas Magnus University \\ E-mail:jan.zukovskis@vdu.lt \\ ORCID ID: 0000-0002-8124-9195
}

DOI: 10.13165/PSPO-21-28-03

\begin{abstract}
Everyday, the fashion industry turns out millions of garments. Increasing garment manufacturing costs and the cost of both imported and domestic raw materials are two of the toughest issues facing this industry and for this reason, supply - chain management is crucial in the fashion industry. Another issue is that while many of us are familiar with the concept of supply chain management, they are unsure of how to put it into practise or how to properly plan for it. Complete understanding of the SCM and its role in fashion industry in Nigeria. This reseqrch work helps to increase enviromental awareness and policies and also investigate the supply chain management approach for fashion retail store

This research was achieved through extensive literature review and emperical data analysis. The survey design of the research involves a set of questions and statements to which participants give answers
\end{abstract}

Keywords: Supply chain, management, fashion industry, environmental impact, quality, system

\section{Introduction}

Globally, the fashion industry employs over 75 million people and generates over US $\$ 2.5$ trillion in revenue each year. The industry has grown rapidly in the last two decades, with production doubling between 2000 and 2014. People are buying 60\% more clothing in 2014 than they did in 2000, but they only wore it for half as long (David, et al., 2009). As the fast fashion industry grows at a percent per annum of $21.9 \%$ from 2020 to 2021 , the industry is expected to expand $\$ 30.58$ billion in sales by then. As a result of the recovery from the COVID19 impact, companies have resumed operations and are adapting to a new normal while recovering from the operational challenges caused by social distance, remote working, as well as the closure of commercial activities, which had previously led to limiting containment measures. The market is anticipated to grow at a 7\% CAGR until 2025 to reach $\$ 39.84$ billion. In the fast-fashion industry, clothing and accessories are sold in line with current trends, along with services that support them. When clothing moves quickly from catwalk to the store, it is said to be fast fashion. Fashion Week serves as a springboard for fast fashion designers' clothing collections. Because of low living wages as well as unsanitary working condition and as result fast fashion is struggling. Workers in the fashion industry, particularly women (nearly $80 \%$ of a world's textile workers are women), are paid pitifully little. As with men, women are also subjected to harassment and discrimination at work. Fast fashion garment workers in Asia, as per the Global Labor Justice survey, face exploitation and mistreatment, including poor working conditions and low pay as well as excessive overtime that reduces productivity. As a result, the fashion industry will be despised by the majority of people. The expansion of the fast - fashion industry is therefore harmed by the low wages and the appalling working conditions. The fast fashion industry was propelled by the growing number of young people who wanted 
fashionable but affordable clothing. As estimated by the United Nations, there will be 1.2 billion young people in the world in 2019 and that number will rise by $7.9 \%$ to 1.35 million by 2030 . Clothes that are one-of-a-kind, trendy, and affordable are particularly popular among the youth population. As a result, clothing manufacturers are putting their efforts into bringing customers the latest fashions from New York Fashion Week. As the population of young people grows, so does their affordability for fast fashion clothing. Despite the fact that the fashion business is on the rise, greater attention has been paid to the wide range of environmental harms for which the industry is primarily responsible. Fashion production is responsible for ten percent of all human carbon emissions, as well as depleting freshwater supplies and polluting rivers and streams. Furthermore, according to (McFall-Johnsen, 2020), every year, 85\% of textiles end up in landfills, and clothing washing releases massive volumes of microplastics into the ocean.

The performance indicator developed in Nigeria by EPI (Anon., 2018) highlighted the fact that we have not yet fully implemented the sustainability policies in the monthly report on green production and sustainable waste management. Nigeria will be close to achieving the goals of the ecosystem and the environment, if it works well on the goal of sustainable development.

Table 1.Environmental performance index of Nigeria (Anon., 2018)

\begin{tabular}{|l|l|c|c|}
\hline Sl. No & Measurement index & Current rank & Current score (\%) \\
\hline 1 & Air quality & 152 & 48.08 \\
\hline 2 & Water and sanitation & 168 & 7.75 \\
\hline 3 & Heavy metals & 60 & 61.39 \\
\hline 4 & Biodiversity & 102 & 71.64 \\
\hline 5 & Forests & - & - \\
\hline 6 & Fisheries & 21 & 69.17 \\
\hline 7 & Climate and energy & 10 & 73.85 \\
\hline 8 & Air pollution & 15 & 84.51 \\
\hline 9 & Water resources & 134 & 30.76 \\
\hline 10 & Agriculture & 72 & 32.93 \\
\hline
\end{tabular}

\section{Problems/limitation of the study}

The research encountered the issue of lack of appropriate technical support. Also, there was the issue of lack of knowledge about standards such as the environment protection agencyand ISO standard to support the green supply chain

\section{Research tasks to achieve the aim}

To achieve the aim of the research certain tasks are needed to be carried out. They includes:

Complete understanding of the SCM and its role in fashion industry.

Reviewing the earlier literature or research work already done in this field, in order to get an idea about the loopholes yet present in this research area. 
Studying about the several International and national organizations that are working for the environmental sustainability in fashion industry. We will also focus on government initiatives taken in this direction earlier and the changes that are needed to be addressed in this field.

Preparing a research methodology, to understand the public awareness regarding this problem via set of questionnaires. Since, no matter how many steps are taken by government or organization but the real change can be done by the common public only.

Suggesting several ways for tackling this situation and analyzing public feedback on this matter.

Providing research data results and providing suggestions and recommendations.

\section{Research design}

For analyzing the SCM in fashion industry, we will focus on Quality Management System (QMS) being adopted by this industry to survive in the competitive environment. This analysis will provide a broader perspective of the SCM in fashion industry and measures required regarding ecological impacts. QMS can help producers standardize processes, adopt best practices in the industry and improve percentages directly (rework). To face the challenge, mode manufacturers are exploring QMS techniques like TQM, ISO \& Six - Sigma Quality Systems more and more. It has been noted that the firefighting environment and the slow adaptation of best practices make it very difficult with in fashion industry to maintain the quality management system. In contrast to traditional product standardization quality control systems, the ISO system places emphasis on process standardization. The system emphasizes process parameter documentation (process KPI) and input indicators (fabrics, trims, utility and workforce) as well as measuring and analytical variables (audits \& corrective/preventive actions) to improve production processes. It aims to control process indicators (by standardizing the processes) while monitoring input - indicators (raw material). The implementation of ISO QMS is based on four phases in apparel production: define, document, document - control, \& measurement and analysis to improve the process. This analysis will provide overview of fashion industries. Now, for the research work, survey research design will be used. Survey design can be seen as a non-experimental research design used to describe an individual or a group of individuals by administering a survey or a questionnaire. The survey design of the research involves a set of questions and statements to which participants give answers. The survey design was also demonstrated as a survey or self-report, since many surveys specifically contain questions about themselves in which participants report.

For these reasons, the survey research - design will be adopted:

1 Survey data have been collected from many individuals at relatively low costs and relatively fast, based on the survey design.

2 The survey conducted by the researchers is very attractive if sample generalization is a research objective.

3 Survey studies conducted here are often the only way to develop a representative overview of the attitudes $\&$ characteristics of a huge population.

The questionnaire was mainly structured to consist of closed questions and Likert-types in order to generate feedback from the respondents about their experiences with the fashion supply chain.

In Section A of questionnaire, the demographic component is obtained, providing general information on respondents, including age, gender, occupation and education. In Section B, dependent as well as independent variables are examined. 


\section{Proposed data analysis method}

In this research data were analysed using descriptive and inferential data analysis methods. Descriptive analysis is a collection of concepts and methods used to organise, summarise, table and describe data gatherings. It gives an overview of what took place in the study. This study included descriptive statistical analysis.

Distribution of frequency: The most common method of summarising data is to calculate frequency distribution \& percentage distribution. It includes data and graphs to describe various types of variables. Researchers can label frequency or percentage charts. It also gives a clear picture of the population and the general section.

\section{Supply chain management in fashion industry in Nigeria}

Definition of Supply Chain :

A global network, to deliver products and services, starting from providing raw material to the consumers using an organized flow of information, physical distribution and payment. Currently it includes also networks for disposal and recycling.

Supply Chain Management:

A network of connected and interdependent organizations mutually and co-operatively working together to control, manage and improve

Goals of SCM :

1. Effective deployment of Supply Chain

2. Synchronizing of supply and demand

3. Global Measurement of Performance

4. Greater value

5. Establishment of a competitive infrastructure

Nigeria's fashion industry plays an important role in revitalizing the economy, attracting foreign direct investment and sustaining the livelihood of the public. However, due to the rapid growth of the industry and the lack of awareness of environmental management in the supply chain, the disposal practices of Nigerian manufacturers are of major concern. The disposal method used by manufacturers in Nigeria is simple disposal by incineration or landfill. It releases acid gases, dioxins and dust particles that are harmful to humans and the environment. The purpose of this document is to identify the drivers, factors and methods needed to implement sustainable supply chain management in the Nigerian garment industry. The method is based on an extensive literature review focusing on barriers to recycling and waste reduction, environmental performance indicators, factors contributing to the achievement of a sustainable supply chain, and the types of waste generated by the Nigerian garment industry. The review shows that Nigerian apparel manufacturers must implement sustainable supply chain management to achieve sustainability and profitability. By this research is needed on the environmental impact of reuse and recycling in Nigeria's fashion industry. Comprehensive research into environmental supply chain management can be key to promoting sustainable development and overall environmental performance across Nigeria's manufacturing sector.

In a series of efforts to revive the economy and attract direct foreign investment, the Nigerian government has divided its economy into a manufacturing sector similar to the clothing industry. The clothing industry today is one of the most lucrative, popular and fastgrowing businesses among Nigerians. The Nigerian commodity business contributes continuously to economic development, direct foreign investment, and livelihoods (about 60\%) in the manufacturing sector. (ZO., 2014) 
Therefore, Nigerian textile and textile firms are part of small and medium enterprises that require the concept of supply chain (suppliers, services and asset management) in their operations. Clothing workers worldwide are estimated at 26.5 million people with a trade value of US \$ 1.7 trillion in 2012 according to the International Labour Organization's production statistics database (Anon., 2012).

In order to achieve lasting competitive advantage in the garment industry, there must be a constant demand for textile products supported by population growth and economic development. Over the years, there are growing concerns about disposal techniques or recycling methods used by clothing manufacturers in Nigeria. Most of the waste identified during production includes; Fabric and wool debris, defective pieces caused by ironing and other damage to the assembly, box boxes, zippers, buttons, cords, and stickers.

\section{Frequency distribution in terms of percent}

For each data point or collection of data points, a percentage frequency distribution shows the number of observations that are present as a percentage of the total. When describing the relative frequency of survey replies or other data, this is a very helpful way to do so. Tables, bar graphs, and pie charts are frequently used to show percentage frequency distributions.

\section{Data analysis}

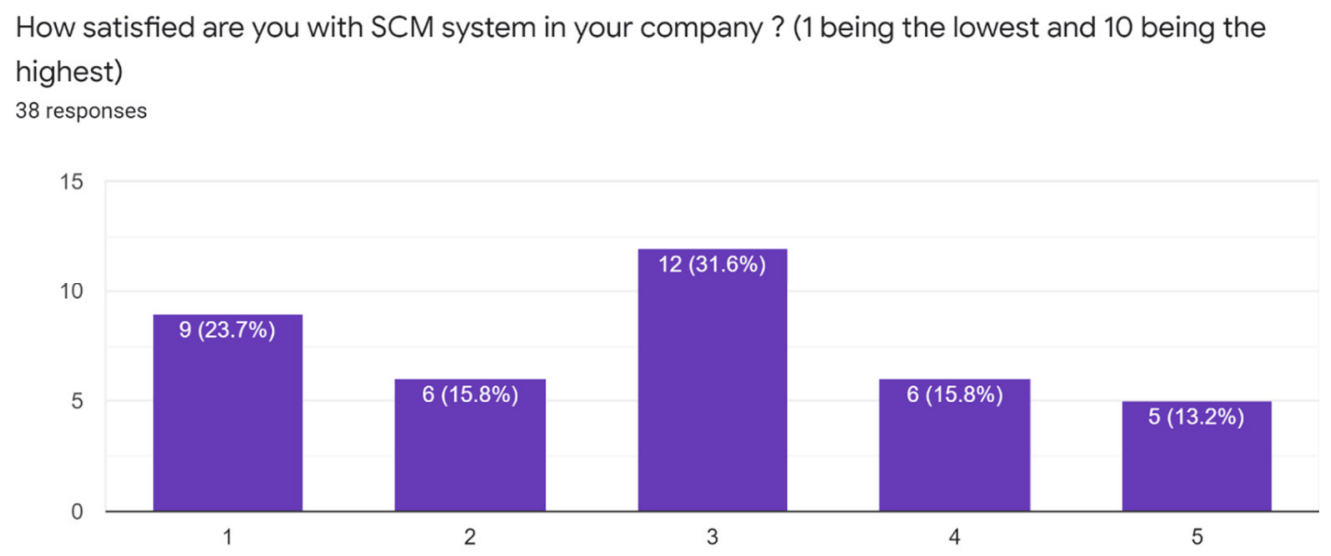

Figure 1.Analysis of rating of SCM in Fashion Industry (Anon., 2021)

According to you what are the ecofriendly strategies followed in Your Company 38 responses

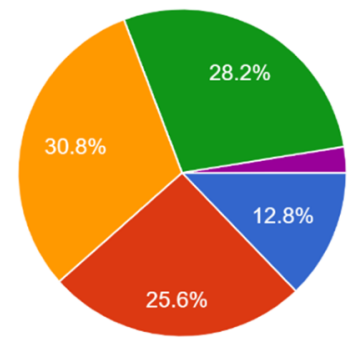

Reactive Strategy (Low - Level)

Focused Strategy (High -Level)

Opportunistic Strategy (Medium Level)

Proactive (Latest Environmental

Strategies)

Don't know

Figure 2. Analysis of opinion about ecofriendly strategies in Fashion Industry (Anon., 2021) 
The above pi diagram show the percentages of respondent's experience about ecofriendly strategies in the field of fashion industry in Nigeria and the obesevation are as follows

\section{Conclusions}

Fast fashion lowers the cost of clothing while increasing the environmental impact. Fashion has been the second-largest consumer of freshwater in the world, accounting for $10 \%$ of global carbon emissions. Flying internationally, using single use plastic bags, and even commuting to or from work are all well-known environmental blights of modern living. Though less evident, climate change has less of an impact on the things we wear. Fashion industry characterised by fast changes in trends as well as, with short product life-cycles and by large assortments, demands responsive/demand led Supply Chain focusing on items availability, actual information sharing \& speed in meeting customers' requests. In this perspective, this thesis proposes alternative studies and models that, combined in an effective Decision Support System, can allow firms to optimise performance of their Supply Chains. During a preliminary risk assessment of the overall framework of a traditional supply chain operating in this industry, it became clear that the most important goal is the ability to respond to market fluctuations, i.e. the correct time management, and the most important process to perceive this goal is the product distribution to the system of directly run stores, often known as replenishment. This thesis offers a solution to these issues by outlining a supply chain performance optimization in fashion industry. It's hard to predict what will happen to the garment supply chain in the future. Retailers in the fashion industry must devise innovative inventory management and supply chain management solutions. As retailers continue to explore for solutions to these prevalent problems, more helpful technologies will be included into the process and wider issues with in fashion industry will be addressed, such as sustainability. As a result, customers seek out cruelty-free items in greater numbers. It will be critical to meet this demand.

As people all over the world buy more garments, the expanding market for low-cost items and trendy new designs is having an adverse impact on the environment. More people bought clothing in 2014 than in 2000, a rise of $60 \%$ on average. As much as $10 \%$ of all carbon emissions come from the fashion industry's water use and pollution of our rivers and streams.

Furthermore, every year, 85 percent of all textiles are disposed of in landfills. To top it all off, washing some garments releases huge amounts of plastic into the environment. Here are some of the most severe environmental consequences of the fast fashion industry.

As a result, the fashion business is unquestionably expanding in a fast-paced atmosphere. Apparel makers and retailers would have benefited greatly from knowing what influences consumer interest in and intention to buy clothes. In light of it's critical for manufacturers to be competitive in the garment \& retail industries. Retailers, marketers, and other relevant stakeholders must work more to acquire and keep customers. Relevant to the potential clients' wants and demands. Recognizing the things that pique your interest. Their target market's interest in apparel can help them segment their customers more precisely and effectively promote the brand and build customer loyalty. The study's conclusions are particularly relevant now, given the increased inflow of overseas brands of clothing. Thus, this research have examined the environmental damages caused by fashion industry and reasons behind it. This is very alarming situation for the sustainability of our environment. This research focuses on major areas causing environmental damage and steps should be taken immediately to combat this problem. 


\section{References}

1. David, C., Dave, E., Susan, M. \& Ole, J., 2009. The consumer decision journey [online]. [Online] Available at: http://www.mckinsey.com/business-functions/marketingandsales/our-insights / the-consumer-decision-journey [Accessed 25 July 2021].

2. Geneva enviroment network, 2021. Environmental Sustainability in the Fashion Industry. [Online] Available at: https://www.genevaenvironmentnetwork.org/resources/updates/ sustainable -fashion/ [Accessed 15 september 2021].

3. McFall-Johnsen, M., 2020. These facts show how unsustainable the fashion industry is. [Online] Available at: https://www.weforum.org/agenda/2020/01/fashion-industrycarbon-unsustainable-environment-pollution/ [Accessed 13 september 2021].

4. Adegee, D.-A., 2020. Wastewater: fashion's grotesk sustainability problem. [Online] Available at: Roughly $20 \%$ of industrial wastewaters worldwide comes from fashion industry [Accessed 22 september 2021].

5. McFall-Johnsen, M., 2020. These facts show how unsustainable the fashion industry is. [Online] Available at: https://www.weforum.org/agenda/2020/01/fashion-industrycarbon-unsustainable-environment-pollution/ [Accessed 5 september 2021].

6. Anon., 2021. Author, s.1.: s.n.

7. Anon., 2014. Mckinsey Global Institute.. Nigeria's renewal: Delivering inclusive growth in Africa's largest economy;

8. Anon., 2018. United Nations Environment Programme (UNEP).

9. Anon., 2019. United Nations Environment Programme, s.l.: https://www.unep.org/newsand-stories/story/putting-brakes-fast-fashion.

10. MacArthur, E., 2017. A New Textiles Economy: Redesigning Fashion's Future. Ellen MacArthur Foundation, .

11. Rodriguez, A. T. a. L., 2020. UNCTAD. [Online] Available at: https://unctad.org/news/ textile-and-garment-supply-chains-times-covid-19-challenges-developing-countries [Accessed March 2021].

12. Anon., 2019. A New Textiles Economy: Redesigning Fashion's Future, s.l.: http://go.nature.com/2Cj3ndP.

13. Kirchain, R. O. E. R. M. T. \&. G. S., 2015. Sustainable Apparel Materials. Materials Systems Laboratory.

14. Anon., n.d. europart.eu, s.1.: s.n.

15. Fiber2fashion, 2020. s.1.: https://www.fibre2fashion.com/industry-article/6262/variouspollutants-released-into-environment-by-textile-industry.

16. Ellram, M. L., 1991. Supply Chain Management; the Industrial Organization Perspective,. Internationa journal for physics distribution and logistics management, pp. 21(1):13-22.

17. Wisner, D., 2003 . A Structural Equation Model of Supply Chain Management Strategies. Journal of Business Logistics, pp. 24(1):1-26. 
18. Ellram, L. M. W. L. T. a. K. J. P., 2013. Offshoring and reshoring: An update on the manufacturing location decision.. Journal of Supply Chain Management, p. 49: 14-22..

19. Kotler, P. a. A. G., 2010. Principles of Marketing. New Jersey: Pearson Education.

20. Diaconu, D. a. A. C., 2014. Strengths and Weaknesses of Current Supply Chain management and initiatives for the future. International management conference, pp. $1165-1172$.

21. Allwood, J. M. S. E. L. C. M. D. R. a. N. M. B., 2006. In The Present and Future Sustainability of Clothing and Textiles in the United Kingdom. London. Institute for Manufacturing, University of Cambridge.

22. Chen, S. \&. F. K., 2013. Relationship configurations in the apparel supply chain,. Journal of business and industrial marketing, pp. 28(4) pp:304 -316.

23. Cao, M. a. Z. Q., 2011. Supply chain collaboration: Impact on collaborative advantage and firm performance. journal of operation management, pp. 23(9) pp: 163 -180.

24. Perez-Franco, R. S. M. a. S. Y., 2010. Expressing a firm's supply chain strategy: A frame work and manuscript. massachusetts institute of technology.

25. Raipur, O., 2012. Effect of Supply Chain Management on Customer Satisfaction.

26. Toivonen, T., 2016. Overview of fashion industry's production networks and possibilities of shoter supply chain. Tampere university of technology.

27. Fletcher, K., 2008. Sustainable Fashion \& Textiles: Design Journeys..

28. Tokatli, N. a. O. K., 2009. From Manufacturing Garments for Ready to Wear to Designing Collections: Evidence from Turkey.”. Environment and planning, pp. 41:146-62.

29. Tokatli, N. (., 2007. Global Sourcing Insights from the Clothing Industry: The Case of Zara, A fast fashion retailer. A journal of Economic geography, p. 8: 21-38.

30. Solomon, M. a. N. R., 2004.. Consumer Behaviour in Fashion. Englewood Cliffs, NJ: Prentice-Hall..

31. ZO., O., 2014. An assessment of factors militating against fabric production in contemporary Nigerian textile industry. Nigeria, http://www.sciencedomain.org/reviewhistory/27358.

32. Anon., 2012. Global employment trends, s.1.: https://www.ilo.org/global/lang-en/index.htm .

33. Anon., 2018. Environmental Performance Index (EPI) Survey Report. , s.1.: http://epi.yale.edu/epi/country rankings. 